\title{
KOLABORASI MERAWAT BRANTAS (SEBUAH STUDI KOMUNIKASI LINGKUNGAN DI DESA SUMBER BRANTAS, KOTA BATU, JAWA TIMUR)
}

\author{
Oleh: \\ Victor Kurniawan P, Anang Sudjoko, dan Antoni \\ Prodi S2 Ilmu Komunikasi, Fakultas Ilmu Sosial dan Politik, Universitas Brawijaya \\ E-mail: vkurniwan@gmail.com, anangsujoko@ub.ac.id, ant_ui@yahoo.com
}

\begin{abstract}
Intisari
Penelitian ini bertujuan untuk mendeskripsikan Komunikasi Lingkungan dalam merawat Daerah Aliran Sungai (DAS) Brantas, di desa Sumber Brantas, Kota Batu. Penelitian ini dilakukan untuk memperkaya kajian Komunikasi Lingkungan dalam konteks Asia. Penelitian ini menggunakan pendekatan kontruktifis dengan metode penelitian kualitatif dengan pemilihan informan Purposive Sampling. Metode pengumpulan data dilakukan dengan wawancara mendalam (indept interview) dan observasi partisipan (overt participant) guna mendapatkan data yang akurat dari informan sesuai dengan kebutuhan. Hasil penelitian ini adalah adanya kolaborasi antara perum Jasa Tirta, Tahura Soerya, dan masyarakat dalam merawat Daerah Aliran Sungai Brantas (DAS) yang difasilitasi oleh pemerintah desa Sumber Brantas. Kunci dari kolaborasi yang efektif dalam merawat DAS Brantas adalah: Kesadaran akan nilai strategis Brantas, pemahaman terhadap peran masing-masing intitusi, aspek budaya. Hasil penelitian ini menunjukkan bahwa Komunikasi Lingkungan di desa Sumber Brantas dipengaruhi oleh pemahaman setiap stakeholder, nilai DAS Brantas, dan juga aspek budaya.
\end{abstract}

Kata Kunci: Komunikasi Lingkungan; Kolaborasi; Konservasi; Komunikasi Perspektif Asia

\begin{abstract}
The aim of this research is to depict Environmental Communication in order to keep the existence of Brantas riverside, at Sumber Brantas Village, Batu. Moreover, it would give richer information of Environmental Communication in Asia Context. This research using social constructivism paradigm and qualitative descriptive approach. In addition, purposive sampling method is applied in choosing the right informant. The result show that a collaboration has been developed among perum Jasa Tirta, Tahura Raden Soerya, and people's who live in Brantas Riverside which is supported by the government of Sumber Brantas as mediator. The awareness of strategic value of Brantas riverside, self understanding of every institution about its function, and cultural aspect are the effective keys to accomplish the idea of this research. The data comes from indepth interview and overt participant for the purpose of getting the accurate information. In short, the result of
\end{abstract}


this research shows that culture anda background knowledge of every stakeholder affect the Environmental Communication in the Brantas riverside.

Keyword: Environmental Communication, collaboration, conservation, communication in Asian Perspective.

\section{A. PENDAHULUAN}

Komunikasi lingkungan sebagai sebuah bidang kajian komunikasi berkembang begitu rupa dalam tiga dekade terakhir (Hansen \& Cox, 2015). Perkembangan kajian komunikasi lingkungan tidaklah terjadi begitu saja, ada proses dan tahapan sehingga kajian ini berkembang (Senecah, 2007). Munculnya kajian komunikasi lingkungan dilatar belakangi oleh peningkatan perhatian publik terhadap krisis lingkungan yang terjadi karena perubahan iklim (Cox, 2010), polusi dan menipisnya sumber daya alam (Nasir \& Ahmad, 2013). Isu mengenai lingkungan merupakan persoalan sosial yang mendapat perhatian serius, sebab hal tersebut mengancam masyarakat dan kehidupan organisme lain di bumi. Selain itu, kajian komunikasi berkembang bukan hanya karena faktor persoalan lingkungan, tetapi disebabkan karena manusia yang tinggal di bumi setiap saat membentuk, bertukar, dan menerima pesan mengenai rumah mereka, bumi. Jadi, komunikasi lingkungan terjadi sepanjang waktu dan setiap manusia adalah komunikator lingkungan (Jurin, Roush, \& Danter, 2010).

Kajian ini sangat berkembang di barat. Dunia barat, secara khusus Amerika Serikat dan Eropa, kajian komunikasi lingkungan dikembangkan oleh para sarjana komunikasi melalui berbagai pendekatan. Beberapa pendekatan untuk mengkaji komunikasi lingkungan, diantaranya: Kajian retorika untuk mempelajari konflik terkait persoalan hutan, pertanian, dan spesies-spesies yang terancam punah (Cox, 1982; Oravec, 1981; Oravec, 1984; Lange, 1990; Short, 1991), kajian komunikasi lingkungan yang dikaitkan dengan peran sains, media, dan industri untuk merespons ancaman terhadap kesehatan masyarakat dan kualitas lingkungan (Cox, 2010). Kajian-kajian ini bersinggungan dengan krisis. Itulah sebabnya, beberapa ahli komunikasi mendefinisikan kajian ini sebagai kajian krisis (Senecah, 2007) dan kegagalan institusi sosial dalam merespons krisis tersebut (Schwarze, 2007). Selain itu, kajian komunikasi lingkungan juga berkembang dalam bidang kajian public relation dan media cetak yang mengkonstruksi wacana mengenai persoalan ekologi dan isu mengenai nuklir terutama untuk merespons musibah nuklir di Chernobyl (Cox \& Pezzulo, 2012).

Perkembangan kajian-kajian komunikasi lingkungan ini, memicu munculnya Society of Enviroment Journalis, Environmental Communication : A Journal of Nature and culture pada tahun 1990 an (Cox, 2010), dan terbentuknya International Environmental Communication Association untuk mengkoordinasi aktivitas penelitian komunikasi lingkungan di seluruh dunia pada tahun 2011 (Cox \& Pezzulo, 2012). Di Indonesia perhatian mengenai tentang kajian lingkungan sudah dimulai sejak tahun 1960 walaupun hanya menampilkan berita mengenai lingkungan hidup dari dunia barat. Selain itu, kajian mengenai komunikasi lingkungan lebih banyak ditekankan pada kajian yang bersifat 
pragmatis dan terkait dengan pemberitaan lingkungan (Armando, Sarwono, Triputra, \& Irwansyah, 2011). Walaupun demikian, ada usaha untuk memikirkan pengembangan kajian ini di Indonesia. Pada tahun 1980-an, seorang sarjana komunikasi Indonesia, Alwi Dahlan mengusulkan penelitian mengenai komunikasi lingkungan. Tujuan mengangkat isu ini untuk adalah untuk memelihara relasi antara pemerintah dengan masyarakat terkait dengan persoalan lingkungan hidup (Rambo, 1985). Alwi Dahlan secara khusus merintis kajian-kajian komunikasi lingkungan di Indonesia dalam beberapa topik, yaitu : terkait dengan pembangunan berkelanjutan (Dahlan, 1986), topik lingkungan sebagai salah satu alternatif dalam pemberitaan media massa (Dahlan, 1989), dan peran media dalam perlindungan terhadap lingkungan hidup (Dahlan, 1994). Beberapa tahun lalu, usaha untuk mengangkat tema komunikasi lingkungan kembali dilakukan dalam Konferensi Komunikasi Nasional dengan tema "Membumikan Ilmu Komunikasi di Indonesia”, yang diselenggarakan di Universitas Indonesia pada tahun 2011. Walaupun demikian, pembahasan mengenai komunikasi lingkungan masih sangat sedikit sehingga perlu ada dorongan untuk meneliti kajian komunikasi lingkungan di Indonesia mengingat potensi alam Indonesia.

Dalam penelusuran penulis, ada beberapa penelitian terkait komunikasi lingkungan yang dilakukan oleh beberapa peneliti. Pertama, adalah penelitian yang berjudul Komunikasi Lingkungan dalam Mengembangkan Hutan Berkelanjutan (Herutomo, 2013). Penelitian ini berfokus pada pemeberdayaan masyarakat yang tinggal di hutan yang dikelola Perhutani sehingga dapat menjadi rekan dalam merawat hutan. Kedua, adalah penelitian yang berjudul Peliputan Isu Lingkungan dan Pembangunan Berkelanjutan (Sobur, 2005). Penelitian ini berfokus pada komunikasi lingkungan dalam kaitan peliputan isu lingkungan untuk mendukung pembangunan yang berkelanjutan. Topik yang belum banyak disinggung terkait dengan penelitian komunikasi lingkungan di Indonesia adalah terkait dengan kolaborasi komunikasi lingkungan dalam rangka untuk menjaga kelesatarian lingkungan. Komunikasi lingkungan yang terjadi di desa Sumber Brantas, kota Batu dapat menjadi pembelajaran yang penting yang untuk mengembangkan kajian ini.

Brantas merupakan salah satu Daerah Aliran Sungai (DAS) yang penting di Indonesia, secara khusus di Jawa Timur. Sungai ini melewati dua kota yang penting di provinsi Jawa Timur, yaitu Malang dan Surabaya (Asian Development Bank, 2016). Daerah aliran sungai Brantas memiliki tangkapan hujan seluas $11.800 \mathrm{~km}^{2}$, memiliki panjang 320 km (Subijanto, Harianto, \& Ruritan, 2013), dengan potensi air 12 milyar $\mathrm{m}^{3} /$ tahun (Sunaryo, 2013). Sungai Brantas bermula di pegunungan di sekitar kota Malang dan berakhir di lautan yang berjarak sekitar $30 \mathrm{~km}$ sebelah selatan kota Surabaya (N.Bullock \& Burton, 1988).

Hulu daerah sungai Brantas merupakan salah satu pusat produksi tanaman hortikultura, terutama kentang, kubis, wortel, bawang merah, bawang putih, kacang merah, apel dan tanaman perkebunan seperti tebu lahan kering (Koffel, 1998). Kondisi agro ekologi di wilayah ini sangat mendukung untuk pertanian. Tak hanya itu, Daerah Aliran Sungai (DAS) Brantas merupakan penghasil tenaga listrik, pemasok air irigasi untuk pertanian, memasok air untuk keperluan rumah tangga, dan dikembangkan untuk pariwisata (N.Bullock \& Burton, 1988). Namun, sebagian besar wilayah di DAS Brantas mempunyai indeks erosi yang sangat tinggi. Hal ini memacu adanya usaha untuk 
melestarikan sumber daya lahan, baik secara teknis, biologis, dan ekonomi (Waskito, 2013). Bahkan, dikatakan bahwa DAS Brantas sudah kritis sejak tahun 1970 (Waskito, 2013). DAS Brantas adalah yang paling kritis dari 29 DAS di Jawa Timur. Hampir separuh dari wilayah DAS sungai Brantas termasuk dalam lahan kritis. Isu lingkungan yang paling menonjol di kawasan ini adalah a) alih guna lahan dari hutan menjadi tanaman sayursayuran, b) penurunan kuantitas dan kualitas air, dan c) degragasi lahan (Widianto, D, Sudarto, \& Lestariningsih, 2010). Hal ini cukup memprihatinkan mengingat nilai strategis dari daerah aliran sungai Brantas. Padahal, pemerintah Indonesia sudah memiliki regulasi yang memadai untuk mengatasi permasalahan lingkungan secara khusus pelestarian dan pengelolaan sungai.

Regulasi yang diterbitkan pemerintah menunjukkan kepedulian pemerintah terhadap lingkungan hidup secara khusus DAS. Peneliti mencatat ada dua undang-undang dan peraturan pemerintah yang diterbitkan pemerintah sebagai dasar untuk pengelolaan air dan DAS, yaitu: Undang-Undang No. 7 tahun 2004 tentang Sumber Daya Air dan khusus untuk pengelolaan DAS, pemerintah mengeluarkan Peraturan Pemerintah No. 37 tahun 2012 terkait pengelolaan DAS dan Peraturan Pemerintah No 38 Tahun 2011 terkait dengan sungai. Didasarkan pada Undang-undang dan Peraturan Pemerintah tersebut, maka pemerintah provinsi Jawa Timur menerbitkan Keputusan Gubernur Nomor 188/325/KPTS/013/2010 mengenai penyusunan rencana pengelolaan Daerah Aliran Sungai Brantas terpadu untuk memikirkan pengelolaan Daerah Aliran Sungai Brantas dengan lebih baik. Hal ini menunjukkan perhatian terhadap Daerah Sungai Brantas dan juga berimplikasi kepada keterlibatan berbagai organisasi pemerintah, non pemerintah dan masyarakat yang terlibat dalam pengelolaan DAS Brantas.

Organisasi yang terlibat dalam pengelolaan daerah aliran sungai Brantas adalah sebagai berikut: Pengelolaan menjadi tanggung jawab BPDAS (Balai Pengelolaan Daerah Aliran Sungai) dengan mitra Dinas Kehutanan, Perum PERHUTANI, dan Taman Hutan Raya (TAHURA) Soeryo. Selain itu, berbagai lembaga lain yang memiliki tanggung jawab yang terbatas terkait DAS, seperti BPSDA (Balai Pengelolaan Sumber Daya Air), Proyek Kali Brantas (PU), Dinas Pengairan, Bappedal (Badan Pengendalian Dampak Lingkungan), Dinas Lingkungan Hidup, Perum Jasa Tirta, Dinas Pertanian dan BAPEDA/BAPEKO (Badan Perencanaan Daerah/Kota) dan juga masyarakat, individu dan Lembaga Swadaya Masyarakat yang bergantung pada sumber daya air bagi kehidupan mereka.

Kebijakan ini bersesuaian dengan tulisan di beberapa literatur yang menyatakan bahwa komunikasi lingkungan tidak bisa diperjuangkan oleh satu intitusi saja, tetapi harus melibatkan berbagai pihak, seperti: Masyarakat dan komunitas, komunitas pemerhati lingkungan, peneliti, perusahaan dan pelobi bisnis, komunitas anti environmentalis, media dan jurnalis lingkungan, dan pemerintah (Cox, 2010; Hansen \& Cox, 2015; Jurin, Roush, \& Danter, 2010). Keterlibatan berbagai intitusi merupakan sebuah bentuk komunikasi yang disebut collaboration (Cox, 2010). Istilah ini didefinisikan sebagai "contructive, open, civic communication, generally dialogue, a focus on the future, an emphasis on learning, and some degree of power sharing and levelling of the playing field" (Walker dalam Cox, 2010, h. 120). Namun, keberagaman intitusi juga menjadi hal yang menantang, sebab semakin beragam yang terlibat akan menimbulkan keanekaragaman perspektif dalam 
memandang lingkungan oleh masing-masing organisasi dan individu (Eisenhauer \& Nicholson, 2007) yang dapat menimbulkan perselisihan lingkungan (Cox, 2010). Intitusi yang beragam juga terlibat dalam merawat DAS Brantas yang berada di desa Sumber Brantas, kota Batu.

Desa Sumber Brantas merupakan salah satu desa yang menjadi daerah penyangga bagi kawasan Tahura Raden Soerja, dan lokasi dari titik nol sungai Brantas (Setiawan, 2016). Luas wilayah desa Sumber Brantas sebesar 541,136 Ha dan berada di ketinggian 1.400s/d 1.700 di atas permukaan laut. Penggunaan lahan di desa Sumber Brantas didominasi oleh lahan pertanian yakni sebesar 58,82\%, hal ini dipengaruhi oleh kondisi tanah yang subur dan iklim yang menunjang untuk kegiatan pertanian. Jumlah penduduk desa Sumber Brantas sebanyak 4.100 jiwa dan sebagian besar bekerja sebagai petani sebanyak 21,17\%. Sebagian besar dari penduduk desa Sumber Brantas tamat Sekolah Dasar/sederajat.

Di desa Sumber Brantas kolaborasi berbagai intitusi ini untuk merawat Brantas yang melintasi desa ini. Intitusi yang terlibat dalam perawatan Brantas di desa ini adalah Jasa Tirta, Tahura Soerya, pemerintah desa, dan masyarakat. Kolaborasi yang terjadi diantara keempat intitusi ini terjadi secara harmonis. Hal dapat menjadi suatu pembelajaran bagi gerakan konservasi daerah aliran sungai di Indonesia, sekaligus memberikan perspektif komunikasi lingkungan dari sudut pandang Asia.

Deskripsi di atas mendorong peneliti untuk melakukan penelitian mengenai komunikasi lingkungan di desa Sumber Brantas, maka dari itu maka rumusan masalah dari penelitian ini adalah "Bagaimana Komunikasi Lingkungan yang terjadi di desa Sumber Brantas dalam melestarikan Daerah Aliran Sungai Brantas?”

\section{B. TINJAUAN PUSTAKA}

\section{Komunikasi Lingkungan}

Banyak ahli mencoba mendefinisikan kajian komunikasi lingkungan. DA Bakar (2015) mendefinisikan komunikasi lingkungan sebagai "application of various human interest and activities within the environment surrounding them, ranging from the communication to decision making process and procedure to media publicity and ultimately to public attention”. Sedangkan Cox (2010), menjelaskan komunikasi lingkungan sebagai pembicaraan. Menurutnya, komunikasi lingkungan adalah mengenai transmisi pesan mengenai topik-topik lingkungan. Pemahaman Cox sangat dipengaruhi oleh model komunikasi yang dipopulerkan oleh Claude Shannon dan Warren Weaver (1949) yang menjelaskan bahwa komunikasi adalah pengiriman pesan dari sumber kepada penerima (Cox \& Pezzulo, 2012; Cox, 2010; West \& Turner, 2010).

Berbeda dengan Cox (2010) dan DA Bakar (2015), Richard R Jurin, Donny Roush, \& Jeff Danter (2010) menjelaskan komunikasi lingkungan demikian, 'the systematic generation and exchange of human messages in, from, for, and about the world around us and our interaction with it'. Namun, terkait dengan kajian ini, peneliti lebih condong untuk menggunakan penjelasan komunikasi lingkungan yang dikemukakan Mark Meisner (Center For Environmental Communication, 2016), yaitu : 
Environmental communications is communication about environmental affairs. It includes evaluation of how media cover environmental issues, the rhetoric of environmental debates and decision making, and the discourse around how to solve environmental problems. Environmental communication is all of the many forms of communication (interpersonal, group, public, organizational, mass, etc.) that intersect with the social debate about environmental issues and problems.

Berdasarkan penjelasan yang dikemukakan oleh Meisner (Center For Environmental Communication, 2016; Jurin, Roush, \& Danter, 2010), Cox (2010), dan DABakar (2015) komunikasi lingkungan dapat disimpulkan demikian:

1. Komunikasi lingkungan merupakan aktivitas manusia.

Pesan mengenai komunikasi lingkungan hanya ditemukan di dalam interaksi antar manusia. Hal ini didasarkan fakta bahwa manusia sering kali menjadi salah satu sumber persoalan lingkungan (Schwarze, 2007)

2. Manusia tidak dapat tidak berkomunikasi.

Eksistensi manusia adalah untuk berkomunikasi, menerima dan mengirimkan pesan, Namun, akan sangat bijaksana ketika kita berkomunikasi dengan tujuan dan kompetensi, termasuk ketika berkomunikasi mengenai isu-isu lingkungan.

3. Memahami tujuan berkomunikasi.

Komunikasi berhasil ketika pesan dapat dipahami dengan utuh oleh penerima. Banyak pesan disalah mengerti oleh penerima karena ada noise dalam proses komunikasi.

4. Tanggung jawab terhadap keseluruhan proses komunikasi adalah komunikator, bukan penerima.

5. Bumi memiliki pesan untuk dibagikan kepada umat manusia, dan

6. Komunikasi lingkungan melibatkan banyak stakeholder (Eisenhauer \& Nicholson, 2007)

\section{Perspektif Kolaborasi dalam Komunikasi Lingkungan}

Komunikasi lingkungan berdasarkan pembahasan kita adalah sebuah proses, studi, praktik, sarana, dan sistem (Jurin, Roush, \& Danter, 2010). Beberapa ahli lain menambahkan dengan: melibatkan publik (Cox, 2010; Eisenhauer \& Nicholson, 2007), aktivitas/fenomena (Center For Environmental Communication, 2016), dan nexus (Depoe, 2007).

Jurin, Roush, dan Danter (2010) menawarkan model komunikasi lingkungan yang dikembangkan dari pemikiran W. Witt (1973) yang disebut dengan The Communicating Environmental Information Model yang berfokus pada aliran komunikasi yang terjadi di public sphere. Model ini berupaya menggambarkan banyaknya aliran informasi dari berbagai aktor komunikasi lingkungan dalam mengirimkan pesannya kepada publik yang lebih luas. Dalam model ini publik yang berinteraksi dalam proses komunikasi lingkungan adalah sebagai berikut: 


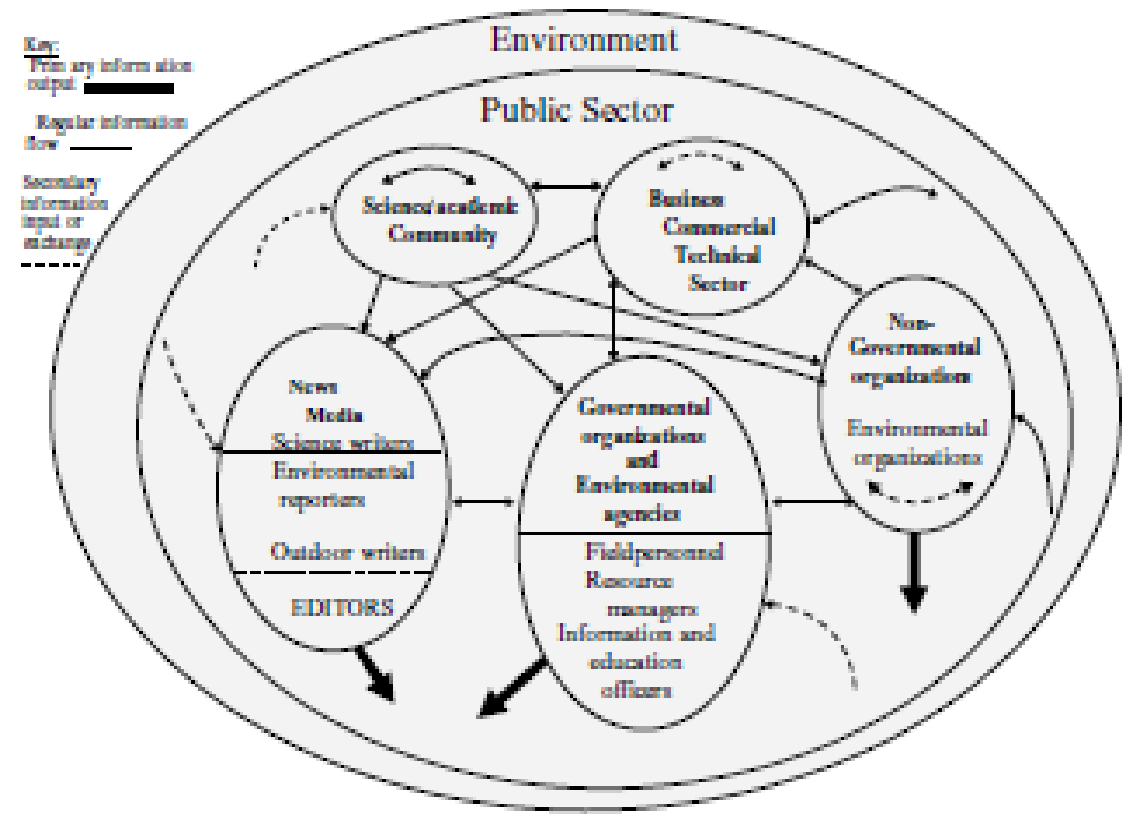

Gambar 1 The Communicating Environmental Model (Jurin, Roush, \& Danter, 2010)

a. Komunitas akademisi

Komunitas akademisi cenderung menjadi sumber informasi. Banyak keputusan sosial terutama kebijakan pemerintah didasarkan kepada pemikiran kaum akademisi. Komunitas akademis membutuhkan sektor lain untuk meneruskan idenya. Saluran yang mungkin untuk meneruskan ide atau gagasan kaum akademisi adalah sebagai berikut :

a) Komunitas akademisi ke sektor bisnis/komersial/sektor teknis. Sektor bisnis berperan untuk memberikan modal untuk proses penelitian.

b) Akademisi ke news media dan.atau organisasi pemerintah dan agensi lingkungan.

c) Sektor Non Govermental Organization (NGO)

d) Sektor publik

b. Sektor Bisnis/komersial/teknikal

c. Media Massa

Memiliki peranan untuk melaporkan dan menganalisa isu-isu lingkungan yang berkembang.

d. Pemerintahan

Kebijakan-kebijakan terkait dengan persoalan lingkungan dibuat oleh pemerintah untuk mendorong terjadinya keterlibatan publik.

e. Non Govermental Organizations (NGO)

Memiliki peranan untuk menyelenggarakan komunikasi persuasif kepada jaringannya dengan menggunakan jaringan informasi yang organisasi ini miliki.

f. Masyarakat atau komunitas lokal 
Model di atas menunjukkan bahwa komunikasi lingkungan melibatkan intitusi yang beragam. Keberagaman intitusi menjadi hal yang menantang, sebab semakin beragam yang terlibat akan menimbulkan keanekaragaman perspektif dalam memandang lingkungan oleh masing-masing organisasi dan individu (Eisenhauer \& Nicholson, 2007) yang dapat menimbulkan perselisihan lingkungan (Cox, 2010). Keterlibatan berbagai intitusi merupakan satu bentuk komunikasi yang disebut collaboration (Cox, 2010). Istilah ini didefinisikan sebagai "contructive, open, civil communication, generally dialogue, a focus on the future, an emphasis on learning, and some degree of power sharing and levelling of the playing field" (Walker dalam Cox, 2010, h. 120).

Untuk mengefektifkan kolabarasi lingkungan ditawarkanlah satu model komunikasi untuk mengakomodasi keterlibatan publik dalam pengambilan keputusan terkait dengan persoalan lingkungan hidup, yang disebut Trinity of Voices (TOV) (Cox, 2010). Model ini terdiri dari tiga elemen dasar untuk menjembatani partispasi publik yang berbeda-beda dalam mengambil keputusan yang terkait lingkungan adalah (Senecah, 2004; Cox, 2010) :

a. Acces: Sumber daya yang dibutuhkan masyarakat untuk berlatih dan berpartisipasi, termasuk waktu dan tempat yang tepat, informasi yang dibutuhkan, dan pendampingan sehingga mereka dapat memahami isu dan dapat terlibat secara efektif.

b. Standing: merupakan penghormatan, dan pengakuan bahwa sudut pandang setiap stakeholder dihargai.

c. Influence: kesempatan setiap partisipan dalam proses yang transparan, kesempatan untuk menemukan alternatif-alternatif, kesempatan untuk menginformasikan keputusan yang diambil dan merespons setiap ide dan perhatian dari setiap stakeholder.

\section{METODOLOGI}

Penelitian ini adalah penelitian kualitatif deskriptif, dengan menggunakan paradigm kontruktivis. Paradigma konstruktivis memandang realitas sebagai konstruksi individuindividu. Pendekatan ini memiliki asumsi bahwa setiap individu mencoba memahami dunia, tempat tinggal dan kerjanya, secara subjektif (Creswell, 2009). Pendekatan konstruktivis dipilih dalam penelitian ini karena aktivitas komunikasi lingkungan di desa Sumber Brantas merupakan sebuah konstruksi sosial yang dihasilkan dari oleh pelaku komunikasi lingkungan di desa Sumber Brantas. Hal sesuai dengan asumsi dasar dari kontruktivis bahwa pengetahuan dikonstruksi secara sosial, dan peneliti harus berusaha untuk memahami dunia yang komplek dari pengalaman hidup orang-orang yang menjalaninya (Schwandt, 2007). Penelitian ini akan menggali pengalaman masing-masing stakeholder DAS Brantas di desa Sumber Brantas dalam merawat Brantas.

Penelitian kualitatif adalah penelitian yang bertujuan untuk menjelaskan fenomena dengan sedalam-dalamnya melalui sudut pandang pelaku (Flick, Kardorff, \& Steinke, 2004) dan bertujuan untuk memahami secara mendalam terkait dengan subjek yang dipelajari (Denzin \& Lincoln, 2005). Secara metodologi, disebut kualitatif karena pembuktian kebenaran mengutamakan empati dan interaksi dialogis antara peneliti dan 
subjek yang diteliti untuk merekonstruksi realitas yang diteliti (Kriyantono, 2012). Teknik pemilihan informan dalam penelitian ini ditentukan dengan cara purposive sampling. Lokasi penelitian ini berada di desa Sumber Brantas, kecamatan Bumiaji, kota Batu. desa Sumber Brantas merupakan titik nol dari daerah aliran sungai Brantas.

\section{PEMBAHASAN}

\section{Kolaborasi untuk Merawat DAS Brantas}

a. Pihak-pihak yang berkolaborasi

Kolaborasi untuk merawat lingkungan, secara khusus DAS Brantas, terjadi di Desa Sumber Brantas. Adapun pihak-pihak yang terlibat dalam kolaborasi ini adalah Tahura Soerya, Perum Jasa Tirta, masyarakat setempat dan pemerintah desa. Setiap pihak memiliki peran khusus dalam merawat DAS Brantas di desa Sumber Brantas.

a. Taman Hutan Raya (TAHURA) Raden Soerya

Taman Hutan Raya Raden Soerya merupakan sebuah kawasan pelestarian hutan alam untuk tujuan koleksi tumbuhan atau hewan yang alami maupun bukan alami, baik asli maupun tidak asli, yang dimanfaatkan untuk kepentingan konservasi sebagaimana yang diatur dalam Undang-Undang Nomor 5 Tahun 1990 yang dikelola oleh dinas Kehutanan. Tujuan keberadaannya berfungsi sebagai perlindungan sistem penyangga kehidupan, keanekaragaman jenis tumbuhan, dan dapat dimanfaatkan untuk tujuan rekreasi. Bagi DAS Brantas Tahura Raden Soerya merupakan daerah resapan air yang sangat penting untuk kelangsungan sungai Brantas.

b. Perum Jasa Tirta

Perum Jasa Tirta merupakan pengelola wilayah sungai Brantas, dan Bengawan Solo dan Jratunseluna. Serayu-Bogowonto serta Toba-Asahan. Terkait dengan wilayah sungai Brantas, Jasa Tirta memiliki peranan untuk mengembangkan pengelolaan sungai Brantas secara efektif dan efisien untuk menjaga keberlangsungan pelaksanaan pengelolaan sumber daya air. Terkait fungsi dan peranan Jasa Tirta 1, maka sebagai bentuk sumbangsih dari Jasa Tirta untuk menjaga DAS Brantas hulu, maka Jasa Tirta membangun Arboretum yang berfungsi sebagai :

1. Ruang terbuka hijau

2. Menjadi area penyerapan karbondioksida dalam skala besar

3. Area penyerap, penyaring, dan penyimpan air saat musim hujan (pencegahan banjir dan menjaga ketersediaan air)

4. Mencegah terjadinya longsor, mengingat semakin sedikitnya ruang terbuka hijau terutama diarea Brantas Hulu

5. Sebagai kebun plasma nuffah pepohonan karena menyediakan berbagai macam keanekaragaman kultivar pohon 
6. Sarana konservasi dengan berbagai koleksi botani khusus dengan berbagai jenis pepohonan.

c. Pemerintah Desa dan Masyarakat Lokal

Pemerintah Desa dan masyarakat setempat menggantungkan sumber air untuk daerah pertanian dan keperluan sesehari dari DAS Brantas. Sehingga, mereka memiliki kesadaran untuk menjaga kawasan DAS Brantas yang melintasi desa mereka, dan mendukung program kerja Tahura Raden Soerya dan Perum Jasa Tirta untuk menjaga kawasan hutan yang berada di sekitar desa mereka dan wilayah sungai Brantas yang mengaliri desa mereka.

Pemerintah desa memiliki peran khusus yaitu sebagai mediator antara intitusi, baik Jasa Tirta atau Tahura Soeryo, dengan masyarakat. Sebagai contoh, petugas Tahura Soerya akan menghubungi pemerintah desa ketika ada warga masyarakat yang merusak hutan yang masuk kedalam wilayah Tahura Raden Soerya. Tujuannya adalah supaya pemerintah desa melakukan pembinaan terhadap warganya sehingga tidak melakukan pelanggaran lagi.

\section{b. Bentuk Kolaborasi}

Bentuk kolaborasi lingkungan yang terjadi di desa Sumber Brantas menggunakan technocratic models of rationality yaitu model kolaborasi lingkungan yang mempersuasi dan mendidik masyarakat setempat sehingga mengerjakan kebijakan-kebijakan, program yang dibuat oleh pembuat kebijakan (Cox, 2010). Dalam konteks di desa Sumber Brantas, masyarakat bergerak atas dasar arahan dari penentu kebijakan dalam hal ini pemerintah desa. Sehingga, ketika Tahura Raden Soeryo dan Jasa Tirta ada program kerja terkait dengan wilayah hutan dan sungai, kedua intitusi ini akan berkomunikasi dengan pemerintah desa untuk kemudian disosialisasikan pada masyarakat desa Sumber Brantas. Hal ini harus dilakukan sebagai bentuk penghargaan terhadap pemerintah desa.

Bentuk kolaborasi lain yang terjadi di desa Sumber Brantas adalah kolaborasi berbasis komunitas. Kolaborasi berbasis komunitas dibentuk berdasarkan konsensus, untuk menangani isu-isu tertentu, bersifat voluntary, dan tidak ada sanksi secara hukum atau peraturan yang mengikat (Cox, 2010). Jasa tirta menggunakan bentuk ini untuk melakukan penghijauan di sepanjang aliran sungai Brantas dan batas-batas lahan. Tahura Raden Soeryo menggunakan basis komunitas untuk menanam bambu disepanjang aliran sungai. Selain itu, setiap tiga bulan sekali setiap intitusi yang berkepentingan terhadap DAS Brantas melakukan penyuluhan untuk meningkatkan kesadaran masyarakat untuk terlibat dalam menjaga kelestarian DAS Brantas dan hutan yang mengelilingi desa Sumber Brantas. Bentuk kolaborasi ini berdampak terhadap peningkatan kesadaran warga dan kelestarian lingkungan. Salah satu contoh, dampak lingkungan dari kolaborasi berbasis komunitas adalah gerakan penghijauan yang 
dilakukan setiap intintusi, Jasa Tirta dan Tahura Raden Soeryo, berdampak pada terpeliharanya sumber mata air di desa Sumber Brantas, yang dulunya tidak mengalir menjadi mengalir lagi.

Bentuk-bentuk kolaborasi yang dilakukan di desa Sumber Brantas menunjukkan bahwa masyarakat, pemerintah, Jasa Tirta, dan Tahura Raden Soerya memperoleh ruang yang cukup untuk terlibat dalam pengambilan keputusan terkait dengan persoalan lingkungan hidup jika dipandang dalam perspektif model Trinity of Voice (TOV) (Senecah, 2004) (Cox, 2010), sebab setiap stakeholder memiliki acces melalui penyuluhan yang dilakukan, standing dengan pengakuan yang diberikan akan nilai penting keberadaan masing-masing stakeholder dalam merawat DAS Brantas, dan Influence dengan memberikan kesempatan untuk terlibat dalam merawat DAS Brantas.

\section{Hal-hal yang Mendukung Kolaborasi Merawat Brantas}

a. Kesadaran akan nilai strategis Brantas

Masing-masing intitusi, dan masyarakat menyadari bahwa Brantas memiliki nilai strategis yaitu menopang kehidupan. Masyarakat setempat menyadari bahwa pertanian mereka sangat bergantung dengan sumber air DAS Brantas, sedangkan Tahura Raden Soerya dan Jasa Tirta yang memiliki kekhususan untuk konservasi dan menjaga sumber daya air, memahami bahwa Brantas mengakomodasi dengan berbagai kepentingan, mulai pertanian, sumber tenaga listrik, air minum, sehingga harus dijaga kelestariannya.

b. Pemahaman Terhadap Peran

Setiap stakeholder menyadari bahwa mereka memiliki peran khusus untuk merawat DAS Brantas. Salah satu yang menolong kolaborasi efektif merawat DAS Brantas di desa Sumber Brantas adalah kesadaran akan wilayah kerja masing-masing intitusi. Tahura Raden Soerya berfokus kepada wilayah hutan, Jasa Tirta berfokus kepada pengelolaan sumber daya air, sedangkan pemerintah berperan menjadi penghubung/mediator dengan masyarakat. Pemahaman terhadap peranan masing-masing menimbulkan sinergi yang baik antar masingmasing intitusi.

c. Aspek Budaya

Masyarakat desa Sumber Brantas sangat menghargai sungai Brantas. Titik nol Brantas yang berada di Arboretum dianggap memberi keberkahan kepada desa Sumber Brantas sehingga harus dirawat. Semangat merawat DAS Brantas ditunjukkan tidak hanya dilakukan dengan kegiatan penghijauan, tetapi juga dengan ritual yang dilakukan di titik nol Brantas yang dilakukan setiap bulan Suro (nama bulan berdasarkan penanggalan Jawa), ketika perayaan bersih desa. Tujuan ritual yang dilakukan untuk memohon keselamatan dan supaya sumber air sungai Brantas tidak pepet (mengecil atau berhenti). Selain itu, masyarakat mempercayai bahwa titik nol Brantas merupakan mahkota sumber air di pulau Jawa yang memiliki kuasa. Kepercayaan ini menyebabkan banyak peziarah yang 
melakukan ritual di titik nol Brantas untuk memperoleh berkah dari sumber Brantas.

\section{E. KESIMPULAN}

Berdasarkan hasil analisis terhadap hasil penelitian bahwa terjadi komunikasi lingkungan yang terjadi di desa Sumber Brantas berbentuk kolaborasi antara pemerintah desa dan masyarakat, Tahura Raden Soerya, dan Jasa Tirta. Bentuk kolaborasi ada dua, yaitu technocratic models of rationality dan berbasis komunitas. Walau demikian, ada ruang yang cukup untuk melibatkan setiap stakeholder dalam merawat DAS Brantas sesuai dengan peran masing-masing. Hal-hal yang mendukung efektifitas kolaborasi dalam merawat DAS Brantas adalah pemahaman akan akan nilai strategis Brantas, peran masingmasing dan Budaya.

\section{DAFTAR PUSTAKA}

Armando, A., Sarwono, B. K., Triputra, P., \& Irwansyah. (2011). Perubahan Iklim dan Dampaknya (Sebuah Kajian Komunikasi Lingkungan). Membumikan Ilmu Komunikasi di Indonesia (pp. 11-19). Depok: Puskakom Press.

Asian Development Bank. (2016). River Basin Management Planning Indonesian Policy and Practice. Philipines: Asian Development Bank.

Center For Environmental Communication. (2016, Mei 16). Retrieved from Center For Environmental Communication: http://www.loyno.edu/lucec/

Cox, R. (1982). The Die is Cast : Topical and ontological dimension of the locus of the irreparable. Quaterly Journal Of Speech, 6, 227-239.

Cox, R. (2010). Environmental Communication and the Public Sphere. California: Sage Publisher.

Cox, R., \& Pezzulo, P. R. (2012). Environmental Communication and the Public Sphere (4th). New York: Sage Publication.

Creswell, J. W. (2009). Research Design : Qualitative, Quantitative, and Mixed Approach Third Edition. California: Sage.

Dahlan, M. A. (1986). Environmental communication: communicating the dilemma of development. AMIC-WCC-WIF Consultation on Beyond Development Communication, Singapore, Nov 18-22, 1986 (pp. 1-28). Singapore: Asian Mass Communication Research \& Information Centre.

Dahlan, M. A. (1989). The environmental orientation: an alternative approach in mass media coverage. AMIC NCBC-BHU Seminar on Media anda the Environment: Varanasi, Feb 26 - Mar 1 (pp. 1-6). Singapore: Asian Mass Communication Research and Information Centre.

Dahlan, M. A. (1994). Expanding The Role of Media In Environmental Protection. AMIC Annual Conference on Communication, Convergence and Development (pp. 1-16). Bangkok: Asian Mass Communication and Information Centre. 
Denzin, N. K., \& Lincoln, Y. S. (2005). The Sage Handbook of Qualitative Research Third Edition. California: SAGE.

Depoe, S. (2007). Environmental Communication as A Nexus. Environmental Communication, 1 (1), 1-4.

Eisenhauer, B., \& Nicholson, B. (2007). Do You See What I See? Diverse Persepective in Environmental Communication. Frontiers in Ecology and Environment, 5(3), 161162.

Flick, U., Kardorff, E. V., \& Steinke, I. (2004). What is Qualitative Research? An Introduction to the Field. In U. Flick, E. V. Kardorff, \& I. Steinke, A Companion of a Qualitative Research (pp. 3-10). Hamburg: Sage Publication.

Hansen, A., \& Cox, R. (2015). The Routledge Handbook of Environmental Communication. New York: Routledge.

Herutomo, C. (2013). Komunikasi Lingkungan Dalam Mengembangkan Hutan Berkelanjutan. Acta Diurna, 37-48.

Jurin, R. R., Roush, D., \& Danter, J. (2010). Environmental Communication Skills and Principles for Natural Resource Managers, Scientists, and Engineers (2nd). New York: Springer.

Koffel, P. (1998). Some impacts of industry pollution in The Brantas River, East Java, and constraints on efforts towards a clean-up: An overview. Environmental technology : applications in principle and practice : proceedings of an International Symposium held at Merdeka University, Malang, Indonesia, July 1-3 1996 (pp. 7182). Murdoch University, Perth, Western Australia: Murdoch University.

Kriyantono, R. (2012). Public Realtions \& Crisis Management Pendekatan Critical Public Relation, Etnografi Kritis \& Kualitatif. Jakarta: Kencana Media Group.

Lange, J. I. (1990). Refusal to compromise: The case of earth first!,. Western Journal of Speech Communication, 54:4,, 473-494.

N.Bullock, \& Burton, M. (1988). Spreadsheets for water management - a case study the Brantas Delta, East Java. Irrigation and Drainage System 2, 259-278.

Nasir, N. N., \& Ahmad, J. H. (2013). Effective Environmental Communication : A Case Study of Environmental Non Goverment Organization (ENGO) In Malaysia. Journal of Social and Development Sciences, 4 (6), 242-248.

Oravec, C. (1981). John Muir, Yosemite, and The Sublime response: A Study of rhetoric of preservationism. Quaterly Journal of Speech, 67, 245-258.

Oravec, C. (1984). Conservationism vs preservationism: The "public interest" in the Hetch Hetchy controversy. Quaterly Journal of Speech, 70, 339-361.

Rambo, A. T. ( 1985). Information Flow in Ecological Systems: A Theoritical Basis For The Study of Environmental Communcation. In AMIC-KLH-EWC Workshop on Environmental Communication Apr 1-3. Singapore: Asian Mass Communication Research \& Communication Centre.

Schwandt, T. A. (2007). The Sage Dictionary of Qualitative Inquiry Third Edtion. California: SAGE.

Schwarze, S. (2007). Environmental Communication as a Discipline of Crisis. Envrionmental Communication, 1 (1), 87-98. 
Senecah, S. L. (2004). The Trinity of voice: The role of pratical theory in planning and evaluating the effectiveness of environmental participatory process. In J. D.-F. S.P Depoe, Communication and public participation in environmental participatory process (pp. 13-33). Albany: State University of New York Press.

Senecah, S. L. (2007). Impetus, mission, and future of environmental communication/division : Are We Still On Track? Were We Ever? Environmental Communication : A Journal of Nature and Culture, 1 (1), 21-33.

Setiawan, D. (2016, November 24). Bhirawa Online. Retrieved from Bhirawa Online: http:/harianbhirawa.co.id/2016/10/mitos-titik-nol-mata-air-sumber-brantas/

Short, B. (1991). Earth first! and the rhetoric of moral confrontation. Communication Studies, 42:2, 172-188.

Sobur, A. (2005). Peliputan Isu Lingkungan dan Pembangunan Berkelanjutan. Mediator, 183-190.

Subijanto, T. W., Harianto, \& Ruritan, R. V. (2013). Key success factors for capacity development in the Brantas River Basin organisations in Indonesia. Water Policy $15,183-205$.

Sunaryo, T. M. (2013, 12 16). Sistem Pembiayaan Pengelolaan SDA WS Brantas. Retrieved from Kemitraan Air Indonesia: www.inawater.org

Waskito, N. T. (2013). Model Budaya Organisasi Dalam Pengelolaan Daerah Aliran Sungai Brantas. Humanity, 75-82.

West, R., \& Turner, L. H. (2010). Introducing Communication Theory Analysis and Aplication. New York: McGraw-Hill.

Widianto, D, S., Sudarto, \& Lestariningsih, I. (2010). Implementasi Kaji Cepat Hidrologi (RHA). Bogor, Indonesia.: World Agroforestry. 